\title{
CHILD'S HEALTH CARE: LEGAL FRAMEWORK AND ONGOING CHALLENGES
}

DOI: 10.36740/WLek202012215

\author{
Oleksandr V. Petryshyn ${ }^{1}$, Marianna I. Liubchenko², Oleksii 0. Liubchenko² \\ 'NATIONAL ACADEMY OF LAW SCIENCES OF UKRAINE, KHARKIV, UKRAINE \\ 2POLTAVA LAW INSTITUTE OF YAROSLAV MUDRYI NATIONAL LAW UNIVERSITY, UKRAINE
}

\begin{abstract}
The aim: Is to analyze the development of the modern legal framework for child's health care, to clarify the benefits of a human rights-based approach, which is now is mainstreaming for understanding the right of children to health and means of its protection.

Materials and methods: To achieve this goal, as well as taking into account the specifics of the topic, the following research methods became relevant: the application of a dialectical approach and historical method made it possible to understand the patterns of formation and development of ideas of children's rights and health within the international community and national states; formal-legal method was used when studying legal texts (international law acts, both of universal and regional level, interpretation and clarification of human rights treaty bodies, expert reports and research, case law), and comparative-legal was used to compare different approaches on health protection in various international human rights mechanisms (US Supreme Court, Council of Europe).

Conclusions: Today, perceptions of children's rights at the doctrinal and jurisprudential levels are quite developed due to a broad understanding and openness to progressive interpretation. In particular, the inclusion into the legal context such determinants as the inviolability of the dignity and private life of the child, proper understanding of the stages of adulthood, and an assessment of the child's developmental environment has made modern international law and national legal systems to become more viable in sense of protection of child's well-being in today's world.
\end{abstract}

KEY WORDS: health, children, human rights, obligations, child welfare, protection

Wiad Lek. 2020;73(12 p. II):2789-2794

\section{INTRODUCTION}

It is not difficult to see that children's health and well-being are the number one target when it comes to violations of children's rights. Just look at some of the examples. According to UNICEF, today more than 230 million children (almost every tenth child in the world!) live in countries or areas affected by armed conflict, of which there are now about 20 [1]. Armed conflicts cause extreme harm to children, the scale of which is difficult to assess, from killings and mutilations to the extermination of the whole generations. This is exactly the trend in Nigeria, where many children have been recruited by the Boko Haram military group, among which dozens of children have been held in military custody for months or years. In addition to the torture and ill-treatment of children, lack of medical care has resulted in the deaths of many children. [2] .

In the context of the spread of the COVID-2019 pandemic, the situation with children's health is in a critical condition. For example, in his most recent report, the Special Representative of the Secretary-General for Children and Armed Conflict reported on the horrific use of quarantine and the reduction in the number of humanitarian missions in conflict-affected regions for military purposes: in particular, Ebola and other diseases treatment centers were attacked by armed groups and looted in order to prevent the provision of medical care. Isolation regime increased risk of sexual and regular violence regarding children and adolescents because of increased presence of military and armed groups in towns and villages; boys and girls, experienced violation, lost the opportunity to obtain immediate and specialized medical and psychological care [3].

Under conditions of relative safety of children's health, however, it is exposed to dangers and fatal effects. Thus, according to State of Global Air estimates, in 2019, 476,000 infants died in the first month of life from health effects associated with air pollution [4] .

All these examples only fragmentarily outline the issue of protecting the health and well-being of children. At first glance, such cases seem completely unacceptable in the 21 st century, when human rights and dignity have the status of the highest value, and the integration of the world's states into international discourse and cooperation is significant. A deeper analysis leads to the conclusion that it is the institutionalization of human rights that has made it possible to identify situations of human rights violations and address these challenges appropriately.

\section{THE AIM}

The aim of this article is to analyze the development of the modern legal framework for protection of children's health, to clarify the benefits of a human rights-based approach, 
which is now the basis for understanding children's right to health and its protection .

\section{MATERIALS AND METHODS}

In order to achieve this aim, taking into account the peculiarities of the topic, the relevant research methods were used: the application of a dialectical approach and historical method made it possible to understand the patterns of formation and development of children's rights idea within of the international community and national states; the formal-legal method was used while studying legal texts, and the comparative-legal method was used to compare different approaches to health protection in different international human rights mechanisms.

The study is based mainly on acts of international law, both of universal and regional levels, interpretation and clarification of human rights treaty bodies, expert reports and research, case law (decisions of the European Court of Human Rights, decisions of the US Supreme Court, decisions of the European Social Rights Committee), relevant scientific literature.

\section{REVIEW AND DISCUSSION}

Childhood is a period of life when people are most vulnerable and are dependent in decision-making on parents or other caregivers. However, the vulnerability of children in no way means that children are perceived as inferior in the exercise of their rights and interests compared to adults. But that was not always in such a way. The evolution of the child's rights took place in the range between the status of the child as an object of parental ownership until the recognition of the child's right to self-determination. Until the first quarter of the XIX century corporal punishment of children and the use of child labor, mostly by parents, were considered to be norm, and infant mortality was high, with one in four births dying. That movement against labor exploitation led to transformation of the concept of childhood, according to which the recognized value of physical, moral and intellectual welfare of the child [5, p. 11]. The first efforts at the international level was made by the League of Nations, which created a special committee to consider matters relating to the protection of children, and adopted conventions prohibiting women and children trafficking (1921) and slavery (1926). In 1924 Geneva Declaration of the Rights of the Child proclaimed an obligation of all adults of the world to provide safety and well-being to children. Three of the five articles of the Declaration dealt with the well-being and health of the child. In Art. 2 adults proclaimed duty to feed hungry children, to nurse a sick child, to help a child who is backward; also in Art. 3 and 4 it was highlighted the need to assist children primarily during disasters and distress, and to ban any of forms of exploitation of children [6]. Later in the 1959 UN Declaration of the Rights of the Child it was declared a duty of parents, men and women both as individuals, as well as public organization and national governments take all measures, including, legislative in order for children to have a happy childhood and be able to exercise their rights and freedoms, in particular those that contribute to the child's health - the right to special protection of physical, mental and social development of the child, the right to adequate nutrition and medical services, the right to special treatment when a child has physical or mental disabilities [7].

The 1948 UN Universal Declaration of Human Rights (UNDHR) proclaimed human rights are to be equally concerned children and adults, with the exception of Art. 25 recognizing that "motherhood and childhood are entitled to special is the care and assistance" and Art. 26, which deals with the prior right of parents in choosing the type of education for their young children". It is also important that the UNDHR is the first international instrument to appeal to human health. Art. 25 of the UNDHR establishes the right of everyone to a standard of living, including medical care and medical care, which is necessary for the maintenance of one's health and well-being of family; it also proclaims the right to security in case of illness [8].

1966 International Covenant on Economic, Social and Cultural Rights (ICESCR) in its Art. 12 imposes on States obligations to fully support "the right of everyone to the highest attainable standard of physical and mental health" and identifies steps that states must take to ensure "achieving progressively the full realization of the rights" to the maximum of its available resources, including through reducing of "the stillbirth-rate and infant mortality" providing "healthy development of the child", "improving of all aspects of environmental and industrial hygiene", preventing of epidemic, endemic, occupational and other diseases, creation "conditions which would assure to all medical service and medical attention in the event of sickness".

It seems there are three features of ICESCR in terms of child: 1) the family as a unit of society is responsible for "dependent children" (par. 1. Art. 10); 2) for the first time a prohibition of discrimination was in the provision of special measures of protection and assistance to children and adolescents, as well as a ban on the use of children in work that is harmful to their health (par. 3 of Article 10); 3 ) it was recognized special protection not only of childhood but also of motherhood, namely protection of mothers during a reasonable period before and after childbirth by providing the necessary social security and paid dismissal (par. 2 of Article 10)[9]

During the second half of the 20th century the rights and legal status of the child have become the subject of philosophical, legal, biological research, the essence of which was mainly to answer the question of how to find a balance between the treatment of children as vulnerable subjects that are in need of special protection and assistance and self-dependent subject, whose rights and status do not differ in any way from that of adults. The authors of the British publication dedicated to children's right to vote and participate in decisions indicated in the work that international recognition of children's rights was based on the notion of children or both of passive, weak and vulnerable beings who need protection, or as recalcitrant 
and menacing, who need control [10]. This approach is called "paternalist" and it is based on the assumption that children are not rational agents and are not able to make their own decisions, are not responsible for errors and vulnerabilities, so it justifies the control and intervention of adults in children's lives. Thus parents, society and state must provide or protect emotional, psychological or physical well-being of children including children's rights to health care, freedom from strict penalties and providing food and clothing. In contrast to the paternalistic liberal approach, based on the children's right to self-determination, recognizes their freedom of choice and thought on issues that concern them: religion or belief, the right to privacy, choice of friends or entertaining, right to express their opinion when they are accused of misconduct [11].

Several decisions of the US Supreme Court deserve to be presented as an example of a liberal approach. In Haley $v$. Ohio case, which concerned detention of adolescent and his stay in the police when it was granted police used a proof manner contrary to law, the Court noted that "Neither man nor child can be allowed to stand condemned by methods which flout constitutional requirements of due process of law" [12]. Another case in which the Court analyzed the content of children's right to freedom of expression in schools noted that public schools may not be "enclaves of totalitarianism" and school officials have no absolute power over their students. The Court stressed that children at school and outside are "persons" under the US Constitution, are entitled to fundamental rights that the State must respect as they themselves must respect their obligations to the state, but students cannot be seen as being forced to communicate on what the state has decided [13]. Soon after, the US Supreme Court reiterated its full understanding of children as bearers of human rights: "constitutional rights do not mature and come into being magically only when one attains the state-defined age of majority. Minors, as well as adults, are protected by the Constitution, and possess constitutional rights" [14].

It turned ironically out that it is the United States to be the only country in the world that has not ratified the Convention on the Rights of the Child (CRC), the adoption of which in 1989 was the turning point in development of children's rights, including health rights [15]. Since its unanimous adoption in 1989 and entry into force in 1990 CRC has become the most widely ratified treaty on human rights, which indicates the willingness of states to adopt comprehensive rules that protect the rights of children, regardless of race, sex, religion, ethnic origin, agency and other, that confirms once again the recognition by all of nations the principle of indivisibility of fundamental rights and duties [16]. The Convention combines modern understanding of human rights, the status of the child and the progressive understanding of the concept of "human health", that is all called "human rights-based approach to health", that is accepted and implemented by World Health Organization together with the Office of the High Commissioner for Human Rights. This approach, implemented in the field of health care, is based on seven key principles: accessibility, acceptability and quality of facilities and services, participation, equality and non-discrimination, accountability, which are expressed in the relevant positive obligations of the state. A "holistic" approach is taken to the understanding of health, according to which the right to health includes timely and appropriate medical care, as well as the main factors that determine its condition - safe and pure water, sanitation, information and education, related to health, and gender equality [17]. Finally, it should be noted that the CRC provisions have become a kind of reconciliation of conflicting theories about the status of the child, as it recognized children as "rational agents" that have the right to participate in decisions affecting their interests, to receive the necessary information (Art. 12, 13), but also considers their "physical and mental immaturity" which requires special safeguards and care (Preambula). The basis for such a compromise concepts of "best interests of the child" and "evolving capacities" (Art. 5).

In its Art. 24 of CRC it was for the first time that the child's right to "the right of the child to the enjoyment of the highest attainable standard of health and to facilities for the treatment of illness and rehabilitation of health" was institutionalized, and states shall strive to ensure that no child is deprived of his or her right of access to such health care services. This wording draws attention to the socio-economic nature of the right proclaimed in Art. 24, which means that its implementation is closely related to the financial capacity of the state. From this point of view, Art. 26 of CRC fulfills this idea, pointing out to the duty of the state to ensure to every child the right to benefit from social security, including social insurance, and to take all necessary steps to achieve the full realization of this right under national law, taking into account available resources and capabilities of the child and the persons responsible for their. Such an approach is extremely important in terms of practical sphere, particularly in terms yof justiciability of these rights, which deserves special attention and study.

Art. 24 lists specific steps by which the state can promote the full realization of the child's right to the enjoyment of the highest attainable standard of health:

(a) to diminish infant and child mortality;

(b) to ensure the provision of necessary medical assistance and health care to all children with emphasis on the development of primary health care;

(c) to combat disease and malnutrition, including within the framework of primary health care, through, inter alia, the application of readily available technology and through the provision of adequate nutritious foods and clean drinking-water, taking into consideration the dangers and risks of environmental pollution;

(d) to ensure appropriate pre-natal and post-natal health care for mothers;

(e) to ensure that all segments of society, in particular parents and children, are informed, have access to education and are supported in the use of basic knowledge of child health and nutrition, the advantages of breastfeeding, hygiene and environmental sanitation and the prevention of accidents; 
(f) to develop preventive health care, guidance for parents and family planning education and services.

However, given one of the key principles of CRC - the principle of non-discrimination (art. 2), and advanced approach to understanding the health of the child - it seems that Art. 24 is not only one to outline the range of remedies of health and welfare of the child proposed by CRC. At least it worth to talk about another four articles: Art. 23, mentally or physically disabled child should enjoy a full and decent life, in conditions which ensure dignity, promote self-reliance and facilitate the child's active participation in the community; Art. 25, which proclaims the right of a child who has been placed by the competent authorities for the purposes of care, protection or treatment of his or her physical or mental health, to a periodic review of the treatment provided to the child and all other circumstances relevant to his or her placement; Art. 27, that proclaims the state responsible to recognize the right of every child to a standard of living adequate for the child's physical, mental, spiritual, moral and social development; Art. 6, which proclaims child 's right to life, survival and healthy development.

The Committee on the Rights of the Child (Committee), established by the Convention, issued General Comments in 2013 [18], where it provided a detailed reading of the right proclaimed in Art. 24 of the Convention, taking into account all trends and challenges for almost 25 years after the adoption of CRC. It is possible to highlight the main theses and messages of this document.

1. A child is treated as a person under the age of $18 \mathrm{in} \mathrm{ac-}$ cordance with Article 1 of the Convention, and childhood is a period of continuous growth from birth to infancy, through the preschool age to adolescence. The stages of the child's development are cumulative and each stage has an impact on subsequent phases, influencing the children's health, potential, risks and opportunities. Understanding the life course is essential in order to appreciate how health problems in childhood affect public health in general. In particular, as to the rights of new-born, the Committee stresses the duty of the state and health care providers to maximize the promotion and support of breastfeeding.

With regard to school-age children and adolescents, the Committee notes the following challenges and approaches to address them:

a) increasing cases of mental diseases within to schoolage children and adolescents, like eating disorders, psychologic injuries, suicides that demand primary care to be developed to early detect and treat such illnesses;

b) obesity is a cause of premature death in children, which requires restricting of influence of "fast-food" that are high in fat, sugar or salt, micronutrient-poor and as well as drinks ontaining high levels of caffeine or other potentially harmful substances, ensuring for all schoolers access to daily nutrition and creating a school environment that promotes healthy lifestyles ;

(c) given the high rate of adolescent pregnancy, states should work to ensure that girls can make independent and informed decisions about their reproductive health, in- cluding abortion; discrimination on the ground of teenage pregnancy such as expulsion from school is inadmissible.

(d) Adolescents in particular need education and training in health care, especially sexual and reproductive education, and have access to all necessary information relating to their health and health services. Article 12 of the Convention emphasizes the importance of children's participation in ensuring that children express their views and take them seriously, in accordance with their age and maturity. States are encouraged to conduct regular participatory consultations that adapt to the child's age and maturity, as well as to conduct research with children and do so separately with parents to learn about their health problems, needs and developmental expectations as a contribution to effective interventions and health programs.

f) gender-sensitive approach, which provides full political participation of young women; expansion of social and economic opportunities; recognition of equal rights in sexual and reproductive health; equal access to information, education, justice and security, including the elimination of all forms of sexual and gender-based violence.

2. The best interests of the child are closely linked to the protection of child's privacy. The Committee believes that children should have access to confidential counseling and advice without the consent of a parent or legal guardian, as well as to certain interventions, such as HIV/AIDS testing, sexual and reproductive health services, including education and recommendations for sexual health, contraception and safe abortion, if it assessed by professionals working with the child, in accordance with the best for the child.

By the way, it should be noted that in 2014, the Optional Protocol to the Convention allowed children to file complaints directly to the Committee on the Rights of the Child, which is an unprecedented decision that strengthened the foundations of children's rights [19].

The broad approach to children's rights reflected in the Convention resulted in relevant trends at the level of regional human rights protection systems. Thus, in accordance with the European Social Charter of the Council of Europe, children and adolescents have the right to special protection against the physical and moral risks to which they are exposed (p. 7 Part 1), have the right to adequate social, legal and economic protection (Art.11); states should guarantee to children and adolescents, taking into account the rights and duties of their parents, necessary care, assistance, education and training, in particular through the creation or maintenance of institutions and services sufficient and adequate to achieve this goal ( $\mathrm{p}$. 17 Part 1). Furthermore, the European Social Committee considered the complaint of the international human rights center INTERIGHTS against Croatia, in which it acknowledged that the fact that Croatian schools do not provide comprehensive or adequate education on sexual and reproductive health for children and youth, and educational materials used in Croatian schools contain some discriminatory statements, it is a violation of Article 11, 16 and 17 of the European Social Charter [20].

The European Convention on Human Rights, the Coun- 
cil of Europe main document on civil and political rights, does not contain references to health rights. However, due to the fact that the European Court of Human Rights often uses an "integrated approach" in interpreting the rights enshrined in the European Convention, it had an opportunity to examine some aspects of health rights, mainly within Art . 2 (right to life) and Art. 8 (right to respect for private and family life). This approach is based on the indivisibility of all human rights and recognizes that, on the one hand, the realization of civil and political rights requires respect for and promotion of social rights, and on the other hand, social rights are not secondary to civil and political rights. That opens doors for creative opportunities to reconceptualize the contours of social rights, including the right to health [21, p. 713]. Let's look at just a few examples of decisions of the European Court of Human Rights. In case of A. R. and L.R. v. Switzerland (admissibility decision) concerned the refusal of the primary school to exempt the applicant's seven-year-old daughter from sex education lessons, due to the applicant's doubts about the usefulness of sex education at the kindergarten and primary school stages. The Court did not regard this as an interference with the applicant's child's privacy (under Article 8 of the European Convention), finding that sex education in primary school had legitimate aims and was, moreover, optional and not systematic; teachers simply "responded to children's questions and actions" [22] .

In case of $P$. and $S$. $v$. Poland 14-year-old rape victim wanted to terminate the pregnancy, but the local government hospital refused to have an abortion and published a press release which confirmed its decision. After that applicants experienced serious pressure from various groups, including medical professionals, journalists, priests and activists against abortion. After appealing the situation in the ministry, she was invited to a secret abortion per 500 $\mathrm{km}$. from her house. The court concluded that Poland had violated its obligations to prevent inhuman and degrading treatment (Art. 3 of the European Convention), as well as its obligations under Art. 8 through the disclosure of personal and medical data of the girl and the creation of barriers in the practical implementation of her right to legal abortion [23] .

Despite significant progress in developing the idea of children's rights and children's health, many challenges lie ahead today. Today's Sustainable Development Agenda prioritizes reducing of infant mortality and under- 5 mortality, fighting female genital mutilation and child abuse, which is now very common in the world. The concept of sustainable development of pays much attention, and the children themselves recognized as a basis for all sustainability dimensions, whose health and education the key to the progressive development of societies [24].

\section{CONCLUSIONS}

The study of the development of the modern legal framework for the protection of the child's health, conducted in this article, allowed us to note a change in approaches to understanding the status of the child and, consequently, to the scope of its rights and opportunities. In the early $20^{\text {th }}$ century the protection of children's interests was limited by the principles contained in the declarative documents. The post-war world has made a significant leap towards the development of safeguards to protect children, recognizing their dignity and respect for fundamental rights. This took place in parallel with the formation of understanding of human health, the actualization of special human needs depending on age and the formation of understanding of the special needs of children.

Inclusive approach that was first embodied in the Convention on the Rights of the Child and the activities of UN Committee on the Rights of the Child, was supplemented in 2014 by creating for children the opportunity to address complaints directly to the Committee. This has not wiped out all cases of injustice and disorder, and a significant number of challenges to the health and well-being of children are facing us all today. But it is the human rightsbased approach that underpins children's health and demonstrates ability to address these challenges.

\section{REFERENCES}

1. UNICEF declares 2014 'devastating year' for millions of children trapped by conflict. Available from: https://news.un.org/en/ story/2014/12/485632-unicef-declares-2014-devastating-yearmillions-children-trapped-conflict [reviewed 2020.08.18].

2. "We dried our tears": addressing the toll on children of northeast Nigeria's conflict / Amnesty International, 2020. Available from: https:// www.amnesty.org.ua/doslidzhennya-vijna-v-nigeriyi-vplyv-na-ditei/ [reviewed 2020.08.18].

3. Report of the Special Representative of the Secretary-General for Children and Armed Conflict (A75 / 203, July 2020). Available from: https://documents-dds-ny.un.org/doc/UNDOC/GEN/N20/189/61/PDF/ N2018961.pdf?OpenElement [reviewed 2020.08.18].

4. Aspecial report on global exposure to air pollution and its health impacts /State of Global Air. Available from: https://www.stateofglobalair.org/ resource [reviewed 2020.08.15].

5. Kosher H, Ben- Arieh A, Hendelsman Y. Children's Rights and Social Work. Springer International Publishing; 2016, 75 p.

6. Geneva Declaration of the Rights of the Child, 1924 . Available from: https://www.humanium.org/en/geneva-declaration/ [reviewed 2020.08.15].

7. Declaration of the rights of the child, 20 November 1959 . Available from: https://www.humanium.org/en/declaration-rights-child-2/ [reviewed 2020.08.18].

8. Universal Declaration of Human Rights, 1948. Available from: https:// www.un.org/en/universal-declaration-human-rights/ [reviewed 2020.08.18].

9. International Covenant on Economic, Social and Cultural Rights, 1966. Available from: https://www.ohchr.org/en/professionalinterest/pages/ cescr.aspx [reviewed 2020.08.18].

10. Hallett Ch, Prout A. Hearing the Voices of Children, Basingstoke: Taylor \& Francis; 2003, 264.

11. Ruck M, Peterson-Badali M, Freeman M. Handbook of Children's Rights. New York. Routledge; 2017.

12. Haley v. Ohio, 332 U.S.596 1948. Available from: https://supreme.justia. com/cases/federal/us/332/596/\#601 [reviewed 2020.08.20]. 
13. Tinker v. Des Moines Independent Community School District, 393 U.S. 503 1969. Available from: https://supreme.justia.com/cases/federal/ us/393/503/\#tab-opinion-1947775 [reviewed 2020.08.20].

14. Planned Parenthood v. Danforth, 428 U.S. 52 1976. Available from: https://supreme.justia.com/cases/federal/us/428/52/ [reviewed 2020.08.20].

15. Convention on the Rights of the Child, 1989. Available from: https:// www.ohchr.org/en/professionalinterest/pages/crc.aspx [reviewed 2020.08.20].

16. Legislative history of the Convention on the Rights of the Child. Volume I. Available from: https://www.ohchr.org/Documents/Publications/ LegislativeHistorycrclen.pdf [reviewed 2020.08.20].

17. Human rights-based approach, $0 \mathrm{HCHR}$ and WHO, 2009. Available from: https://www.who.int/hhr/news/hrba_to_health2.pdf [reviewed 2020.08.20].

18. UN Committee on the Rights of the Child (CRC), General comment No. 15 (2013) on the right of the child to the enjoyment of the highest attainable standard of health (art. 24) , 17 April 2013, CRC / C / GC / 15, Available from: https://www.refworld.org /docid/51ef9e134. html [reviewed 2020.08.20].

19. Optional Protocol to the Convention on the Rights of the Child on a communications procedure, adopted and opened for signature, ratification and accession by General Assembly resolution A / RES / 66/138 of 19 December 2011, entered into force on 14 April 2014. Available from: https://www.ohchr.org/en/professionalinterest/pages/ opiccrc.aspx [reviewed 2020.08.20].

20. International Center for the Legal Protection of Human Rights (INTERIGHTS) v. Croatia No. 45 / 2007. Available from: https: //www. coe.int/en/web/european-social-charter/processed-complaints/-/ asset_publisher/5GEFkJmH2bYG/content/no-45-2007-internationalcentre-for-the- legal-protection-of-human-rights-interights-vcroatia? inheritRedirect $=$ false [reviewed 2020.08.20].

21. Marochini M. Council of Europe and the Right to Healthcare - Is the European Convention on Human Rights an appropriate instrument for protecting the right to healthcare? Coll.Right.fak.Univ.Riyadh. 2013;2(34):729-760.
22. Case of A.R. and L.R. v. Switzerland, Application no. 22338/15, Judgment ECHR, 18 January. HUDOC. database. Available from: https://www.echr. coe.int/Documents/CP_Switzerland_ENG.pdf [reviewed 2020.08.20].

23. Case of P. and S. v. Poland, Application no. 57375/08, Judgment of 30 October 2012 (final 30/01/2013). HUDOC database. Available from: https://hudoc.echr.coe.int/fre\#\{ "itemid": ["001-114098"]\} [reviewed 2020.08.20].

24. GSDR 2015 Brief «Children as a Basis for Sustainable Development». By the Thematic Group on Early Childhood Development, Education, and Transition to Work. Available from: https://sustainabledevelopment. un.org/content/documents/6449100 [reviewed 2020.08.20].

\section{ORCID and contributionship:}

Oleksandr V. Petryshyn: $0000000343204545^{A, E}$

Marianna Liubchenko: 0000-0001-7090-2403 A,B,D,F

Oleksii Liubchenko: 0000-0002-8068-5665 A,B,D,E

\section{Conflict of interest:}

The Authors declare no conflict of interest.

\section{CORRESPONDING AUTHOR} Marianna Liubchenko

Poltava Law Institute of Yaroslav Mudriy National Law University, Poltava, Ukraine e-mail: lyubchenko.marianna@gmail.com

Received: 24.08 .2020

Accepted: 27.11 .2020

A - Work concept and design, B - Data collection and analysis, C - Responsibility for statistical analysis, D-Writing the article, $\mathbf{E}$-Critical review, F - Final approval of the article 